\title{
The Road Towards “Zero Energy” in Buildings: Lessons Learned from SOLARXXI Building in Portugal
}

\author{
Laura Aelenei* , Helder Gonçalves and Carlos Rodrigues \\ ${ }^{1}$ National Energy and Geology Laboratory, Paço do Lumiar 22, 1649-038 Lisboa, Portugal \\ * Corresponding Author, laura.aelenei@ineti.pt
}

\begin{abstract}
In this paper the authors intend to share the lessons learned in the designing process of a solar office building currently underway to reach the Net Zero-Energy performance. Solar XXI building was built in Lisbon in 2006 as a demonstration project [1]. The building, which design is based on a combination of passive design techniques with renewable energy technologies (PV, solar collectors), may be currently considered, from this perspective, a near Net Zero Energy Building. Despite Solar XXI falling short the NZEB status, it is believed that the experience acquired and lessons learned in the designing phase are worth noting. The demonstration of the building energy performance is done by means of experimental monitoring data and energy modelling results using the simulation engine EnergyPlus [2]. In addition of this, it is important to stress out the fact that the authors of this paper, who are participants in the SHC Task 40-ECBCS Annex 52, "Towards Net Zero Solar Energy Buildings" are currently engaged in studying possible strategies for “upgrading” Solar XXI to NZEB status [3].
\end{abstract}

\section{Introduction}

The energy consumption in European Union residential and commercial buildings member states represents approximately $40 \%$ of total final energy consumption. The implementing of energy efficiency measures in buildings through passive design applications is now recognized as a priority due to its potential to invert the statistics. Another strategy currently under investigation to be fully implemented beginning 2019 in Europe is to offset the growing energy demand of building with renewable energy harvested on site (e.g. by means of renewables). When energy efficiency measures (high performance insulation and windows, ventilation heat recovery, architecture sustainable design, high rating appliances) are successfully combined with on-site energy renewable sources, and the energy consumption is equal (or nearly) to the energy production, then the output achieved can be referred to as "near net zero energy", "net zero-energy " or even "positive energy building". Although these terms have different meaning and are often still poorly stated or understood, the net-zero energy building (NZEB) concept may be defined as a building that over a year is neutral, meaning that it delivers as much energy to the supply grids as it uses from the grids [4]. The successful application of this strategy, which in practice may lead to zero energy, depends on choosing the adequate technical strategies that respond better in the local context to the defined objective. In this context the present paper presents the energy performance of the solar office building, Solar XXI, built in 2006 in Lisbon as a demonstration project. The building, which design is based on a combination of passive design techniques with renewable energy technologies (PV), may be currently considered, from this perspective, a near Net Zero Energy Building. Despite Solar XXI falling short the NZEB status, it is 
believed that the experience acquired and lessons learned in the designing phase are worth noting. In addition of this, it is important to stress out the fact that the authors of this paper, who are participants in the SHC Task 40-ECBCS Annex 52, “Towards Net Zero Solar Energy Buildings” are currently engaged in studying possible strategies for "upgrading” Solar XXI to NZEB status.

\section{The main steps towards zero energy}

Net Zero energy building (NZEB) concept may be defined as a building that over a year is neutral (i.e., it delivers as much energy to the supply grids as it uses from the grids) when energy efficiency measures are successfully combined with on-site energy renewable sources. According to this, the net zero-energy performance may be achieved as a result of executing two fundamental steps: first reduce building energy demand, and second, generate electricity or other energy carriers, to get enough credits to achieve the desired energy balance. With respect of Solar XXI building, its design performs both steps. Firstly, it includes a large number of energy efficiency measures and strategies adopted in order to reduce the heating, cooling and lightning loads. Then the PV system integrated on the main building façade together with the parking car shelter PV array, produce energy that cover approximately $78 \%$ of the building electric energy consumption (measured on an annual basis).

\subsection{Reducing the energy demand}

\section{Building urban integration/Location/Climate}

Solar XXI building is located in National Laboratory of Energy and Geology campus (Lisbon) about $10 \mathrm{~km}$ north-west of the Lisbon down town (38 $\left.46^{\prime} \mathrm{N}, 9^{\circ} 11^{\prime} \mathrm{W}\right)$, (Figure 1).

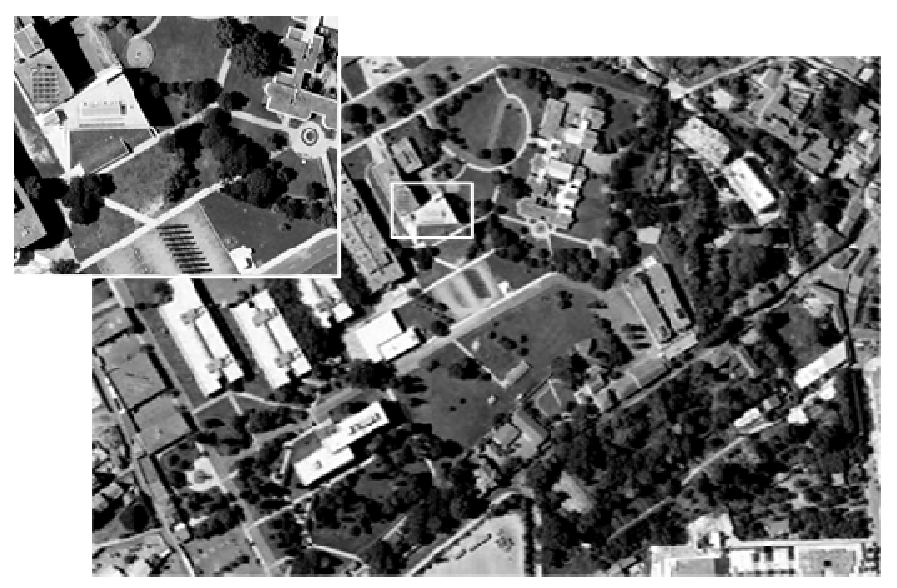

Fig. 1. Solar XXI-location

The neighbourhood is mixed of office and residential buildings and several schools and parks. There is little foot traffic and a medium (low) volume of vehicular traffic. Solar XXI belongs to the National Laboratory of Energy and Geology campus, and serves currently for office for about 20 employees. The Lisbon climate is generally warm and sunny with a heating period of 5.3 month and about 4 month cooling period. The monthly average temperature varies between $10.6^{\circ} \mathrm{C}$ (January) to $22.6^{\circ} \mathrm{C}$ (August). The average number of heating degree days (HDD) is $1190^{\circ} \mathrm{C}$.days, with the average minimum temperature between 8 and $10^{\circ} \mathrm{C}$. In summer time, the solar radiation can reach values of more than 
$6.5 \mathrm{kWh} / \mathrm{m} 2$ per day and extreme temperature values of about $35^{\circ} \mathrm{C}$ or higher, however the maximum average air temperature in the summer is around $28^{\circ} \mathrm{C}$ [5].

\section{Thermal optimization of the building envelope}

One of the strategies adopted in the design of SOLAR XXI building in order to reduce the thermal loads and providing an optimal thermal comfort consisted in the integration of a high quality building envelope. The Solar XXI building envelope consists of a $22 \mathrm{~cm}$ thickness brick masonry wall externally insulated with expanded polystyrene $6 \mathrm{~cm}$ thick. The building roof is externally insulated with extruded polystyrene $10 \mathrm{~cm}$ thick. The windows are made of transparent double glazing using as shading device (in the main façade) external blinds leading to 0.09 summer SHGC. The U-value average envelope of the Solar XXI building is estimated to $0.88 \mathrm{~W} / \mathrm{m} 2 \mathrm{~K}$ and the shape factor is $0.33 \mathrm{~m}^{2} / \mathrm{m}^{3}$. The characterization of the elements of the building envelope is summarized in Table 1 .

Table 1. Building elements thermal properties.

\begin{tabular}{|c|c|c|}
\hline Building elements & Material & U value (W/m $\left.\mathbf{~}^{2} \mathbf{K}\right)$ \\
\hline External walls & Brick wall + ETICS $(6 \mathrm{~cm})$ & 0.45 \\
\hline Roof & Concrete with external insulation $(10 \mathrm{~cm})$ & 0.26 \\
\hline Thermal bridges & Concrete with external insulation $(6 \mathrm{~cm})$ & 0.55 \\
\hline Windows & Transparent double glazing & 3.50 \\
\hline \multicolumn{2}{|l|}{ Envelope (average) } & 0.88 \\
\hline
\end{tabular}

\section{Use of the solar gains / Passive Heating}

The Solar XXI building main façade (South oriented) is covered by windows and PV modules by equivalent proportions (Figure 2). This large glazing area (about $46 \%$ of the south façade and $12 \%$ of building conditioned floor area) interact directly with the office rooms permanently occupied, collecting direct solar energy, providing heat and natural light to these spaces. Increasing the solar heat gains in winter time consisted one of the dominant strategies in the building design, by adopting essential features such as location, size and orientation (south) of the main glazing area.
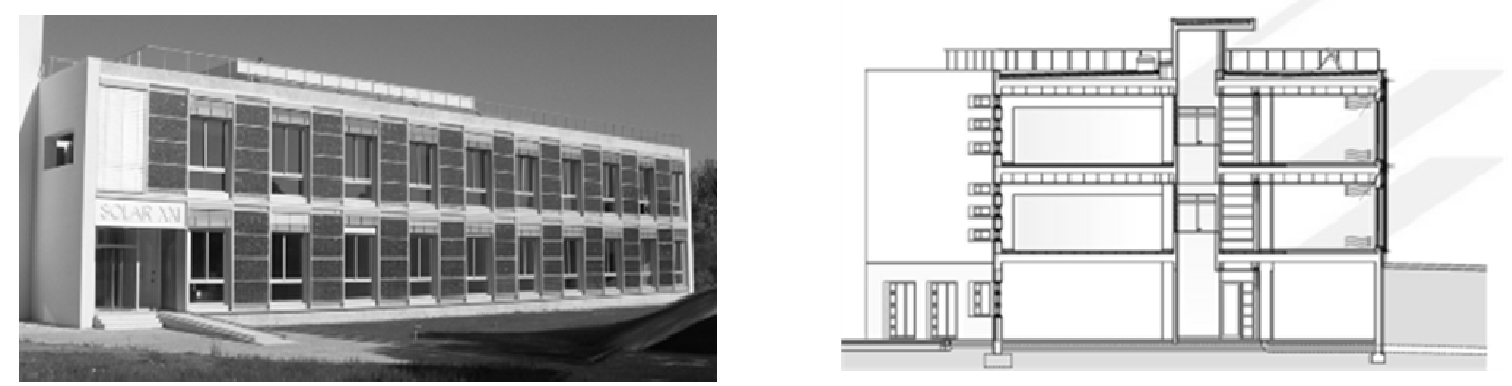

Fig. 2. Direct Solar gains/Solar XXI main façade.

In addition to the use of direct solar gains through the windows, the PV system integrating south building façade (BIPV-T), is also contributing for the improvement of the indoor climate during 
heating season in the day time hours, when the heat released in the process of converting solar radiation into power is successfully recovered. The PV panels are integrated in such a way onto the building façade so that an air cavity is created between them and the building envelope. In this manner the system is constituted of an outer layer (PV panels) and an inner layer (building envelope). The air gap formed between these two layers communicates with the indoor environment by means of two vents (dampers), one located in the upper part and one located the lower part of the brick wall. In addition to this, the system is also designed to allow the gap ventilation exclusively with outdoor air. The strategy of the gap ventilation is simply imposed by its occupants who may manoeuvre the vents manually in the desired position according to their individual comfort needs and weather conditions (Figure 3).
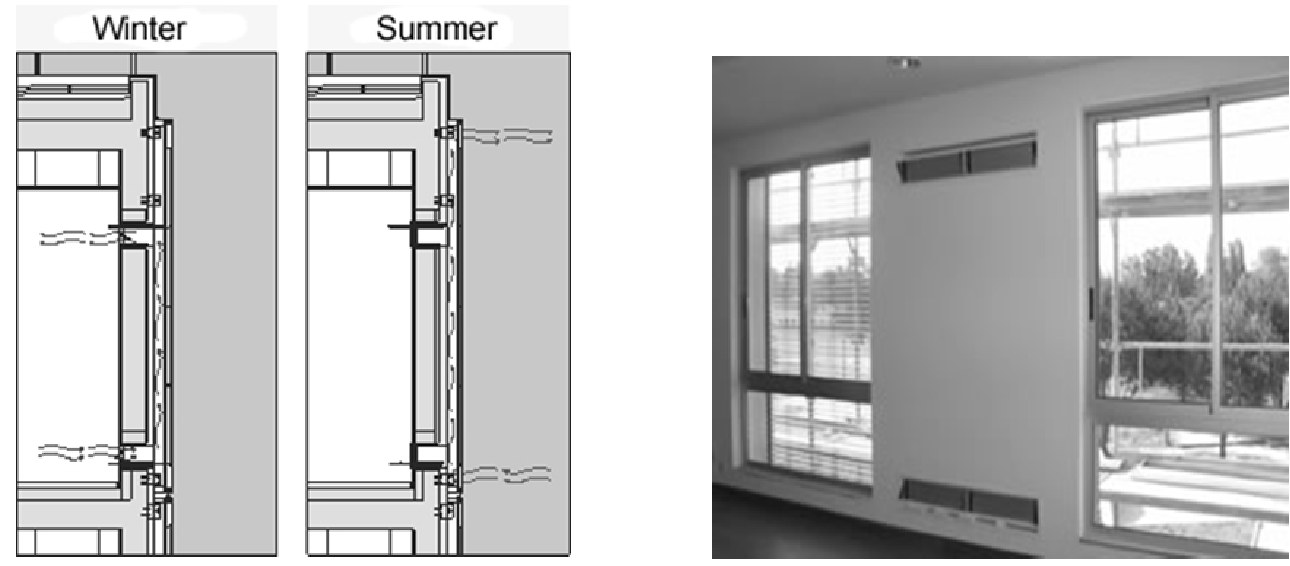

Fig. 3. BIPV-T scheme.

\section{Passive Cooling System}

The Lisbon summer time is characterized by high intensity of the solar radiation, which combined with high temperature values can lead to the building overheating. Solar XXI building uses a set of efficient measures and strategies they are capable to diminishing the building cooling loads. The building has no active cooling system and a number of design measures are incorporated to reduce the summertime heat load. Venetian blinds were placed outside the glazing to limit direct solar gains. A ground cooling system provides incoming pre-cooled air into the building using the earth as a cooling source.
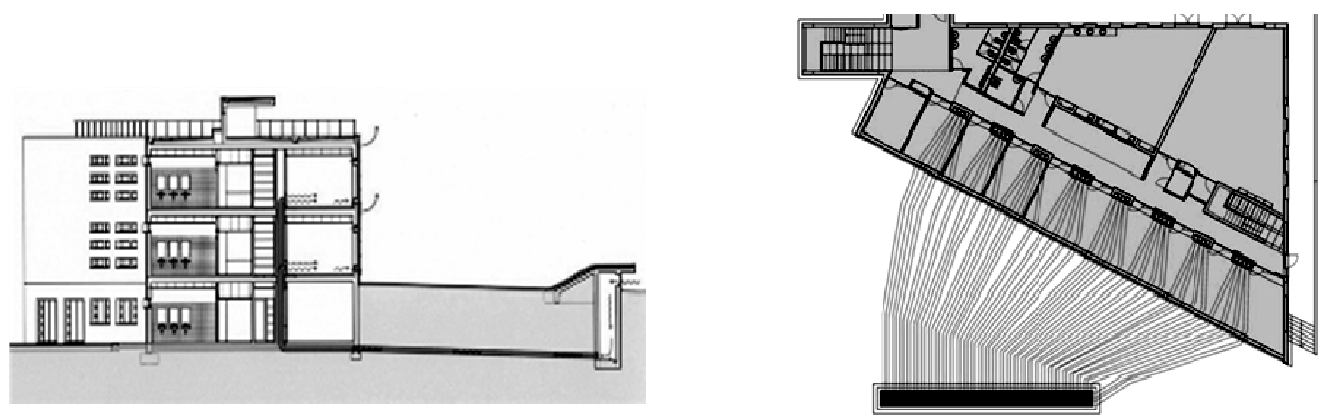

Fig. 4. Earth tube cooling system. 
The system consists of 32 tubes with $30 \mathrm{~cm}$ diameter, buried at $4.5 \mathrm{~m}$ depth (Figure 4). The ground temperature varies from 13 to $19{ }^{\circ} \mathrm{C}$ throughout the year, so it represents an excellent cooling source during summer season. The air enters into the tubes array $15 \mathrm{~m}$ away from the building, cross the tubes circuit cooling to a temperature near the ground and is injected into the building office rooms by natural convection or forced convection using small fans. The system operates with great efficiency in the hot summer days, when the indoor temperature is significantly higher, by pushing the fresh air from the buried pipes. The air temperature injected inside the office rooms ranges between $22-23^{\circ} \mathrm{C}$, resulting in a decrease of the indoor air temperature between 2 and $3^{\circ} \mathrm{C}$.

\section{Natural ventilation/Natural lightning}

The natural ventilation has an important role in this building in both seasons. Natural ventilation is provided due to cross wind and stack effect via openings in the façade and roof level. The façade openings together with adjustable vents on all office room doors provide the cross ventilation, allowing the air to flow from inside to outside and vice versa. In the building central hall there is a skylight, which allows for natural ventilation by stack effect (Figure 5). The set of ventilation strategies (day and night) provide a high comfort level in the summer, especially when applicable during night period minimizing the thermal loads accumulated during daytime within the building and its temperature.
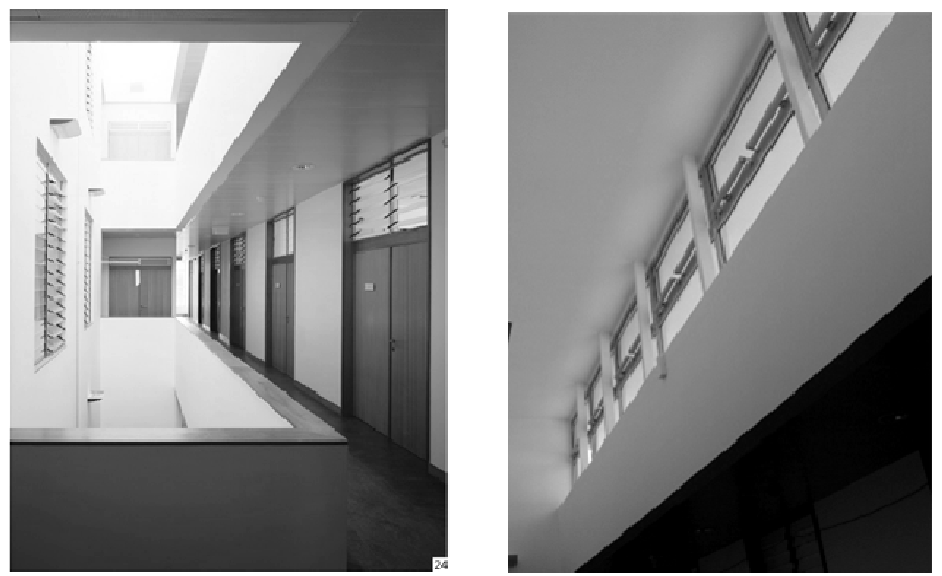

Fig. 5. Natural ventilation/Natural lighting.

Natural light plays an important role in this building. The location and dimension of central skylight as a main light distributor in the central hall is fundamental, as also the translucide vents in the doors which communicate from south and north spaces to corridor and the glazing areas distributed all over the building envelope. These important features adopted in the building design conduct to a reduce electric light building consumption.

\subsection{Generate energy/RES integration}

The integration of renewable energy systems in the Solar XXI design was one of the main objectives of the project. In order to offset the energy demand of the building, Solar XXI uses a $96 \mathrm{~m}^{2}$ array of 76 PV multicristalline silicon modules, mounted on the south building façade, and an additional $95 \mathrm{~m}^{2}$ array of $100 \mathrm{PV}$ amorphous silicon modules, located in the nearby parking car as shading. Until now (2010) the total installed peak power was $18 \mathrm{~kW}$ (12 kW on façade and $6 \mathrm{~kW}$ in parking car) which provided yearly, around 20 MWh. In 2007, the PV façade modules delivered to the internal grid 1004 
$\mathrm{kWh} / \mathrm{kW}$, and the parking car PV system $1401 \mathrm{kWh} / \mathrm{kW}$ [6]. In February 2010 it has been initiated the installation of a new PV system of $12 \mathrm{kWh}$ in the parking car as a complementary shading device. This new PV array of 150 PV CIS thin-film modules, with an area of $110 \mathrm{~m}^{2}$, has an estimated productivity similar to the other PV parking system (1401 kWh/kW). Solar XXI also integrates a roof-mounted array of $16 \mathrm{~m}^{2} \mathrm{CPC}$ solar collectors for space heating. The solar thermal system supplies $11 \mathrm{MWh}$ thermal energy, 5MWh of which being used during the winter time for space heating, mostly in compartments north oriented. The solar system is assisted by a natural gas boiler.

\section{NZEB Energy performance}

\subsection{Building energy performance}

The on-site measurements and the building energy simulation model are important features in the process of assessing the building energy performance. While the physical building features can be modelled with a help of an appropriate simulation tool, the operational characteristics can seldom be defined precisely. One way to overcome the differences between the "real" building and "predicted" building behaviour is to calibrate the simulation model through disaggregation of measured energy use and then "tune" the model to fit the measured data. In the case of Solar XXI building, its energy performance was demonstrated by means of experimental data (on-site measurements) together with modelled data (using the simulation engine EnergyPlus).

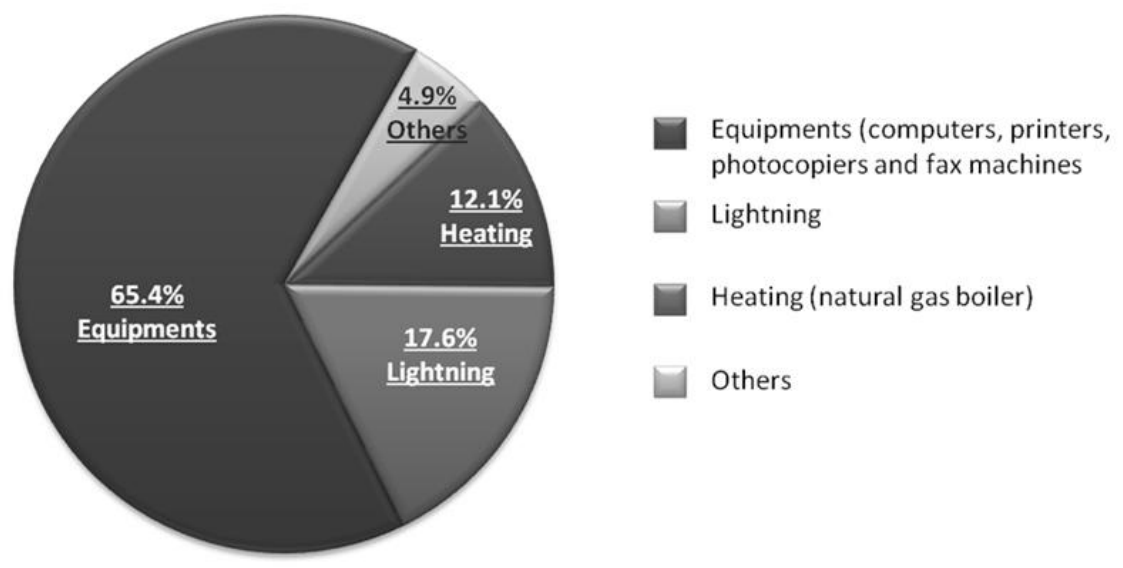

Fig. 6. Distribution of the total primary energy consumption.

The numerical simulations, ran with the objective of calculating the distribution of primary energy, indicate that $65 \%$ is used for office equipments (computers, printers, photocopiers and fax machines) and monitoring equipment (data loggers), $17 \%$ for lightning, $12 \%$ for heating (natural gas boiler) and approximately $5 \%$ for other means (Figure 6).

\subsection{Electric energy consumption/renewable energy supply}

The monitoring analysis performed in 2007 has shown a total amount of electric energy consumption of $27 \mathrm{MWh}$, versus an amount of electricity produced by PV system of $21 \mathrm{MWh}$. In figure 7 is presented the monthly distribution of the electric energy consumed by Solar XXI versus the energy supplied by the PV system (façade + parking) for the 2007. With the increase of the photovoltaic cells 
in the nearby car parking area (operation under course) it is expected an increase in the total annual electric energy production of about 37.27 MWh.

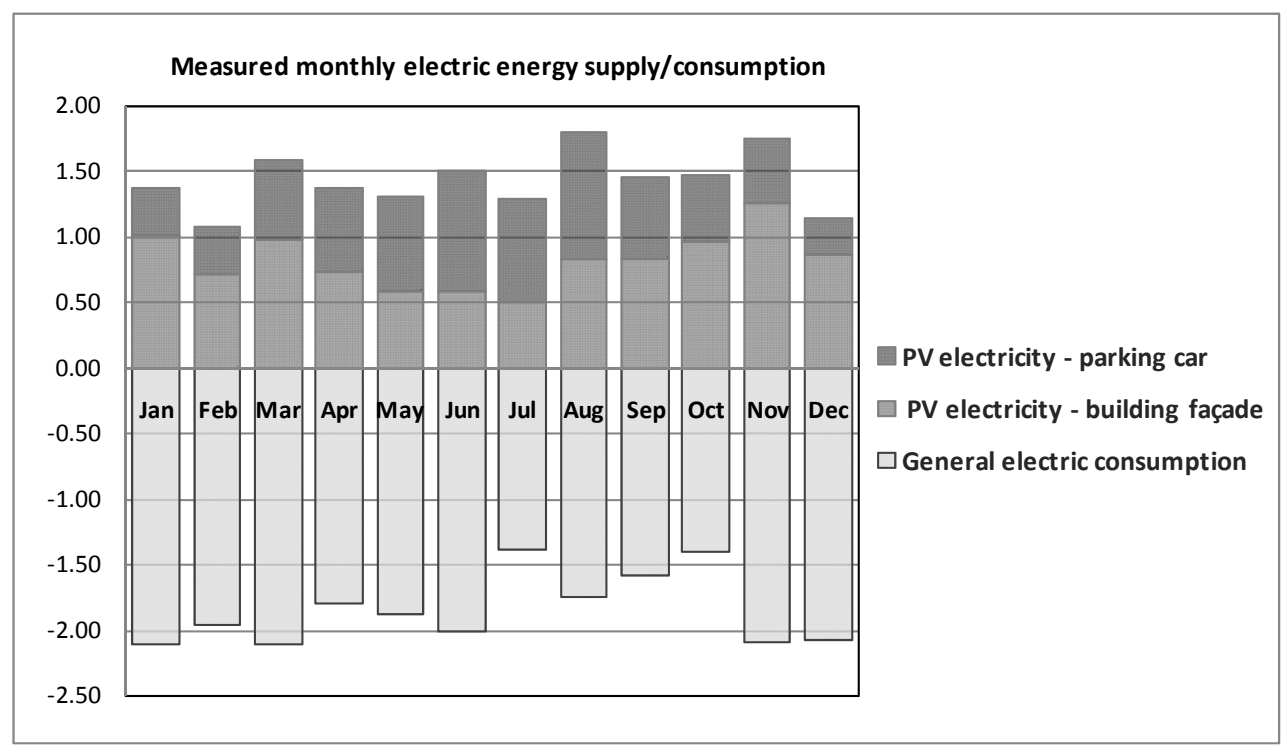

Fig. 7. Solar XXI - monthly electric energy consumption/PV (façade + parking) energy supply.

\subsection{Reaching "zero energy”}

As it has been described in the previous points, the Solar XXI integrates efficient solutions set and strategies, from the features reducing building energy demands, to integration of the renewable energies. Figure 8 shows the 2007 Solar XXI performance from an energy balance approach perspective versus the critical steps towards NZEB performance.

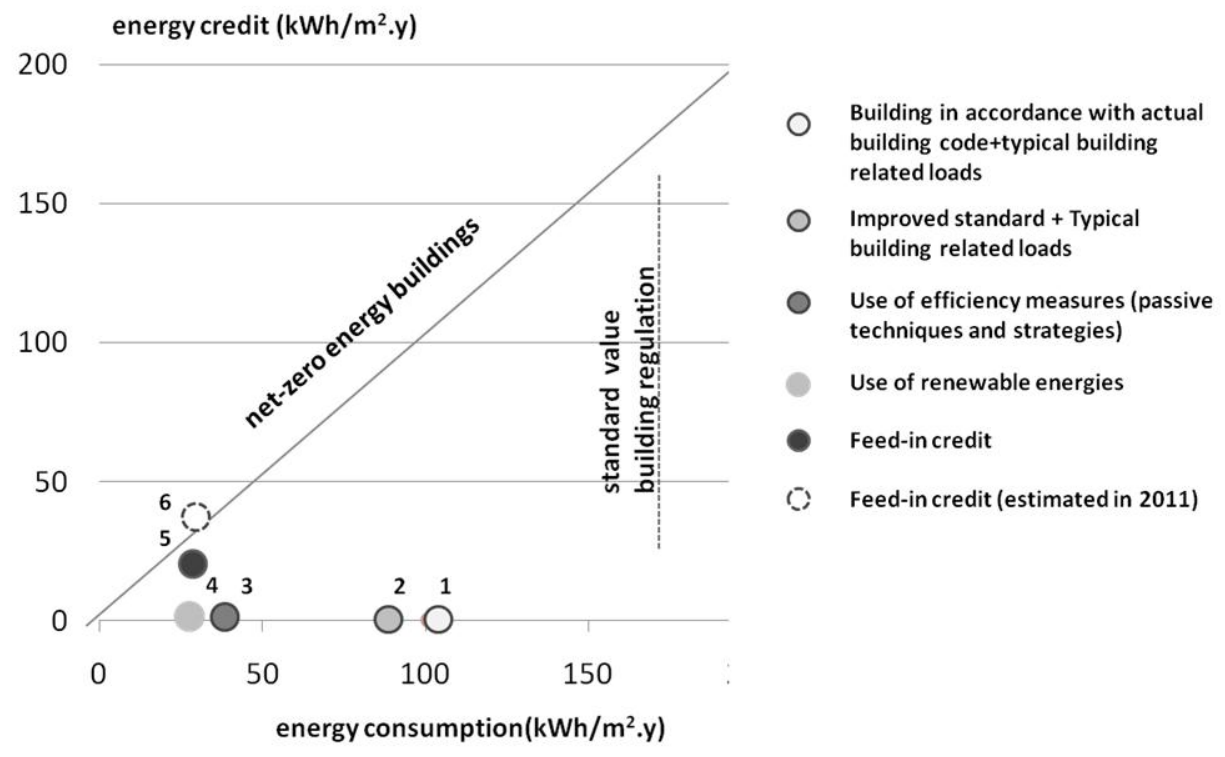

Fig. 8. Solar XXI - the path to net zero-energy performance. 
If designed as an "normal" office building in accordance with the current Portuguese Building Code, Solar XXI would have consumed approximately $101 \mathrm{kWh} / \mathrm{m}^{2} . \mathrm{y}$ including typical user related loads (1). If one performed improvements at level of the building envelope (and still continue with typical user related loads), the building would have consumed $90 \mathrm{kWh} / \mathrm{m}^{2} . \mathrm{y}(2)$. On the basis of the improved building envelope and the outlined passive techniques and strategies, Solar XXI building annual energy consumption is $36 \mathrm{kWh} / \mathrm{m}^{2} . \mathrm{y}$ (3). Taking into account that in 2007 approximately $31 \%$ of the electric energy used from the utility grid was green [7], the building needs to offset decreases to $29 \mathrm{kWh} / \mathrm{m}^{2}$.y (4). This consumption is offset with a credit of $22 \mathrm{kWh} / \mathrm{m}^{2}$.y energy generated by the photovoltaics and solar thermal collectors (5), thus, the final balance of the building points out a near zero-energy performance. However, with the installation of the new PV cells, the feed credit for energy will be increased at $35 \mathrm{kWh} / \mathrm{m}^{2} . \mathrm{y}$, thus, it is expected Solar XXI to become a positive energy balance building.

\section{Final remarks}

With this work the authors were able to share the main findings of the research carried in the design process of an office building currently underway to reach NZEB performance. Along the lines of the paper it has been shown the road traversed by Solar XXI on its way towards reaching zero-energy performance objective. It is believed that the set of solutions adopted the building envelope, the daylighting performance characteristics, the natural ventilation strategies, the passive heating and cooling techniques, together with the integrated renewable energy systems, qualifies the Solar XXI building for exemplary energy performance. Solar XXI building energy performance is about ten times the energy performance of a standard new office building in Portugal [3]. Looking at the energy balance of the building from a NZEB perspective, it was shown that the wise combination of standard and innovative energy performance measures with renewable systems is able to achieve the zeroenergy performance without significant efforts. The authors of this work are hoping that the lessons learned during design, construction and operation of the building will provide useful clues to all interested in developing outstanding energy projects in Southern European countries and not only. At the same time it is also important that this work help policy makers and stakeholders identify (and counteract) the barriers against broader implementation of NZEB's.

\section{References}

[1]H. Gonçalves, P. Cabrito, Proceedings PLEA2006, Switzerland.

[2] EnergyPlus, www.apps1.eere.energy.gov/buildings/energyplus/.

[3]H. Gonçalves et al, (2010). Solar XXI-Em direcção à energia zero / Towards zero energy, @LNEG 2010, Lisbon, (IBSN:978-989-675-007-7).

[4] V. Karsten and M. Riley (2009) “IEA Joint Project: Towards Net Zero Energy Solar Buildings (NZEBs)”, IEA SHC Task 40 - ECBCS Annex 52.

[5] M. J. N. Oliveira Panão, H. J. P. Gonçalves, Proceedings SB10, (2010), Villamoura, Portugal.

[6] C. Rodrigues, S. Viana, A. Joyce H. Gonçalves, A.R. Silva, Proceedings of Eurosun (2008), Lisbon, Portugal.

[7] Direcção Geral de Energia e Geologia, Ministério da Economia e da Inovação. Relatório estatísticas Abril 2010, Portugal. 